\title{
Effects of harrowing and fertilisation on understory vegetation and timber production of a Eucalyptus globulus Labill. plantation in Central Portugal
}

\author{
M. Carneiro *, António Fabião, M.C. Martins, André Fabião, \\ M. Abrantes da Silva, L. Hilário, M. Lousã, M. Madeira \\ Instituto Superior de Agronomia, Tapada da Ajuda, P-1349-017 Lisboa, Portugal
}

Received 21 December 2006; received in revised form 24 July 2007; accepted 6 September 2007

\begin{abstract}
Harrowing and fertilisation are common practices at middle rotation in Eucalyptus globulus Labill. plantations in Central Portugal. In order to clarify the effects of such practices on understory vegetation and timber production, a field trial was installed in a 5-year-old first rotation eucalyptus plantation, in a region with mixed oceanic and Mediterranean climatic influences. Four treatments that involved harrowing (H), fertilisation (F), harrowing and fertilisation (HF), and control (C) were tested in the study. The treatments were replicated four times and arranged in a simple completely randomised design. Vegetation surveys were performed by the quadrat method in the 3 years following treatments and by the line interception method in the 7th and 8th years. Samples of understory biomass were collected, oven dried and weighed. In treatments with harrowing, the understory vegetation consistently had lower number of species, less plant cover, species diversity, and biomass than the other treatments. The mean total number of species only once reached 10 in $\mathrm{H}$ or HF plots, and was always greater than 12 in $\mathrm{C}$ and $\mathrm{F}$ plots in the first 3 years, but decreased in the 7 th and 8th years. In the first 3 years, the understory biomass averaged $30-60 \mathrm{~g} \mathrm{~m}^{-2}$ in the $\mathrm{F}$ and $\mathrm{C}$ plots, and never exceeded $13 \mathrm{~g} \mathrm{~m}^{-2}$ in treatments with harrowing, which corresponded with the proportion of soil coverage by understory vegetation (4-12\% in $\mathrm{H}$ and $\mathrm{HF}$, and $38-62 \%$ in $\mathrm{F}$ and $\mathrm{C}$ plots). In the 7th and 8th years, differences in the understory biomass were less important, but the control plots consistently had the largest understory biomass. The influence of treatments in timber production was not statistically significant at the end of rotation.
\end{abstract}

(C) 2007 Elsevier B.V. All rights reserved.

Keywords: Biodiversity; Biomass; Plant cover; Silvicultural practices; Species richness; Stem volume

\section{Introduction}

The assessment of biodiversity in managed forests has become an important issue for ecosystem study and their longterm sustainability (Aubert et al., 2003; Carnus et al., 2003) since most silvicultural practices result in relevant disturbances to those systems (Bengtsson et al., 2000; Roberts, 2004; Zobrist et al., 2005). However, the information about the potential effects of different management practices on diversity patterns for many forest communities, and particularly the understory vegetation, is not fully known (Roberts and Gilliam, 1995; Neary et al., 2001, 2002; Hartley, 2002; Patel-Weynand, 2002; Carnus et al., 2003; Ramovs and Roberts, 2003). Understory

\footnotetext{
* Corresponding author. Tel.: +3512136533 81; fax: +351213645000. E-mail address: mcarneiro@isa.utl.pt (M. Carneiro).
}

vegetation is one of the indicators of overall biodiversity and ecological sustainability (Bengtsson et al., 2000); the presence of herbs and shrubs in understory may contribute to nutrient cycling, soil carbon content and soil aggregation stability (Tisdall and Oades, 1982; Moore and Allen, 1999; Bauhus et al., 2001).

Eucalyptus plantations in the Iberian Peninsula have frequently been pointed out as low biodiversity ecosystems, since they present poor or no understory vegetation (Rosa et al., 1986; Bernaldez et al., 1989; Alves et al., 1990) as a result of root competition and tree canopy cover. The latter phenomenon is one of the most important factors affecting forest stand understory species diversity and composition by influencing growing conditions via microclimate changes (Roberts and Zhu, 2002). Thus, it exerts a direct influence on the quantity and quality of light reaching the understory vegetation (Cutini et al., 1998; Thomas et al., 1999; Brosofske et al., 2001; Zobrist et al., 
2005), leading to its disappearance, especially of species less tolerant to shade and low soil moisture levels.

Site preparation impacts on the abundance, diversity and biomass of understory vegetation are key factors in forest management and planning. In Portugal, some studies have described the dynamics of understory vegetation over the 1st year following establishment of a eucalyptus plantation (Fabião et al., 2002; Carneiro et al., 2007). However, these studies focused on the effect of soil preparation techniques and harvest residue management related to the intensity of site preparation on understory vegetation. Impacts of silvicultural practices applied later in the rotation have scarcely been studied (Neary et al., 2001) and never reported in Portuguese forest plantations.

Harrowing and fertilisation, 3-5 years following planting, are common practices in Eucalyptus globulus Labill. plantations in Central Portugal in order to control potential fuel load and competition for water and nutrients, thereby improving timber production. Nevertheless, it is still unclear whether these practices promote any significant increment in stem volume or affect the development, abundance and biodiversity of understory vegetation (Alves, 1994). Harrowing obviously constitutes a major form of understory vegetation disturbance, however very few studies have examined the effects of such silvicultural practices in the absence of harvesting. In addition, most fertilisation studies in forests have focused on the effects of nutrient addition on tree growth and have not considered understory communities (Ostertag and Verville, 2002). Therefore, management research on the effect of the most commonly used middle rotation silvicultural practices on understory plant cover should be developed.

This study evaluates the separate and combined effects of harrowing and fertilisation treatment techniques on the abundance and specific diversity of understory vegetation and stand stem volume increment. This information may contribute to the development of optimal management strategies for timber production as well as enhancing understory biodiversity conservation. Together with information obtained from parallel research on site preparation and planting techniques, this information will provide guidelines for intensive forest plantation management.

\section{Methods and materials}

\subsection{Study area}

The experiment was established in April 1996 in a 5-yearold E. globulus plantation at Casal do Vale de Torres (39 $12^{\prime}$ lat. $\mathrm{N}, 09^{\circ} 09^{\prime}$ long. $\mathrm{W}, 140 \mathrm{~m}$ asl), Central Portugal. The stand was planted in November 1991, at $3 \mathrm{~m} \times 1.5 \mathrm{~m}$ spacing, after harrowing with incorporation of slash left from the previous stand (consisting of Pinus pinaster Aiton.) into the soil. Subsoiling up to $80 \mathrm{~cm}$ depth, followed by two plough passes, were used to leave a furrow-hillock soil surface (Marques, 1997).

The climate of the site is of the Mediterranean type with high atmospheric humidity (usually greater than 80\%) in the morning throughout the year due to an oceanic influence, which contributes to reducing the effect of summer drought. The site is situated between the weather survey station of Caldas da Raínha ( $39^{\circ} 24^{\prime}$ lat. N, $09^{\circ} 08^{\prime}$ long. W, 70 m asl) and the rainfall survey station of Torres Vedras $\left(39^{\circ} 05^{\prime}\right.$ lat. $\mathrm{N}, 09^{\circ}$ $17^{\prime} \mathrm{W}, 40 \mathrm{~m}$ asl). In the former, mean annual rainfall is $607 \mathrm{~mm}$, while in the latter rainfall reaches $757 \mathrm{~mm}$. In both cases less than $10 \%$ of rainfall occurs between May and September (Reis and Gonçalves, 1981). The mean annual temperature is $15.2^{\circ} \mathrm{C}$, ranging from a monthly mean of $10.4{ }^{\circ} \mathrm{C}$ in January to $19.8^{\circ} \mathrm{C}$ in August.

The landscape in the study area comprises relatively gentle slopes, ranging between $5 \%$ and $12 \%$. Soils are developed on Cretacic sandstones ("Grés de Torres Vedras"; Zbyzewski et al., 1966) and are mostly Dystric Cambisols and Dystric Regosols (Driessen et al., 2001). These soils are coarse-textured with a coarse sand content exceeding $400 \mathrm{~g} \mathrm{~kg}^{-1}$ and with less than $235 \mathrm{~g} \mathrm{~kg}^{-1}$ of clay. The $\mathrm{pH}\left(\mathrm{H}_{2} \mathrm{O}\right)$ is below 5.3, organic $\mathrm{C}$ content varies between 12.5 and $22.0 \mathrm{~g} \mathrm{~kg}^{-1}$, there are low contents of base cations $\left(2.39 \mathrm{cmol}_{\mathrm{c}} \mathrm{kg}^{-1}\right)$ and extractable $\mathrm{K}$ (50-62 $\left.\mu \mathrm{g} \mathrm{g}^{-1}\right)$, and extremely low extractable $P\left(<5 \mu \mathrm{g} \mathrm{g}^{-1}\right)$ (Marques, 1997).

The potential natural vegetation is of the vegetation series Asparago aphylli-Querceto suberis sigmetum (Costa et al., 2002), dominated by three oak species: Quercus suber, $Q$. faginea subsp. broteroi and $Q$. lusitanica. Sweet chestnut (Castanea sativa) also occurs in the area, as well as Monterey pine (Pinus radiata) which results from occasional seed regeneration from older plantations of this introduced tree species.

\subsection{Experimental design}

The experimental design consisted of four treatments replicated in four different plots in a simple completely randomised design: $(\mathrm{H})$ harrowing; $(\mathrm{F})$ fertilisation; (HF) harrowing and fertilisation together; and (C) control, without any treatments. Each treatment plot area averaged $250 \mathrm{~m}^{2}$ and included approximately 30 measurable trees, separated from measurable trees in the neighbouring plots by at least four tree rows. Harrowing was carried out using a disc harrow (operating up to $20 \mathrm{~cm}$ average depth). A compound fertiliser $(14 \mathrm{~N}: 21 \mathrm{P}: 21 \mathrm{~K}$ in a granulate form) was spread by hand over the soil surface at a rate of $300 \mathrm{~kg} \mathrm{ha}^{-1}$. This corresponded to $42.0,27.6$ and $52.5 \mathrm{~kg} \mathrm{ha}^{-1}$ of $\mathrm{N}, \mathrm{P}$ and $\mathrm{K}$, respectively. In treatment $\mathrm{HF}$ the fertiliser was applied after harrowing.

\subsection{Floristic surveys}

Using the quadrat method (Kent and Coker, 1992), floristic surveys were performed every spring in the 3 years following the application of treatments. A $1 \mathrm{~m} \times 1 \mathrm{~m}$ frame, subdivided by a string in $0.1 \mathrm{~m} \times 0.1 \mathrm{~m}$ squares, was randomly applied four times in each treatment plot. The line interception method (Kent and Coker, 1992) was used in the 7th and 8th year after treatments, using a $15 \mathrm{~m}$ tape four times in each treatment plot. The reason for this change in the survey methodology was due to the increased risk of error when the quadrat method was 
applied in areas where understory woody plants had reached greater dimension and/or higher density over time. The proportion of surface cover of each species was estimated and recorded using both methods. Eucalyptus seedlings from natural regeneration, as well as seedlings of other tree species, such as $Q$. suber, $Q$. faginea subsp. broteroi, $C$. sativa and $P$. radiata, were recorded as understory vegetation whenever present in samples.

\subsection{Assessment of understory biomass}

A wooden frame measuring $0.5 \mathrm{~m} \times 0.5 \mathrm{~m}$ was randomly applied four times in each treatment plot, every spring from 1997 to 1999 (i.e. 1-3 years after treatments), as well as in 2003 and 2004 (i.e. 7 and 8 years after treatments) for above ground biomass sampling. All the understory plants inside the frame were harvested by clipping vegetation close to the ground. They were packed separately in labelled plastic bags, immediately oven dried in the laboratory at $80-85^{\circ} \mathrm{C}$, at least for $48 \mathrm{~h}$, and weighed. The 2004 sampling, performed 13 years after planting, coincided with the end of the rotation.

\subsection{Assessment of stand stem volume}

Tree height $(h)$ of the measurable trees of each treatment plot was measured yearly, from the beginning of the experiment in 1996 until the 7th year after treatment application. This was performed on early phases with a telescoping measuring rod and, on later phases, with a Vertex hypsometer. Tree diameter at breast height ( $\mathrm{dbh}$, diameter at $1.3 \mathrm{~m}$ above ground level) was obtained, in the same trees and years, by taking the mean of two measurements with a calliper in perpendicular directions. Stem volume (SV) was calculated for all trees using an equation based on these parameters (Tomé, 1990):

$\mathrm{SV}=\left(0.3739 \times 10^{-4}\right) \mathrm{dbh}^{1.8151} h^{1.1455}$

\subsection{Data handling and statistical analysis}

Data from floristic surveys were compiled as well as species lists by year and treatment plot. The soil cover proportion of each species and bare soil in each treatment plot were averaged. The Shannon-Wiener diversity $(H)$ and equitability $(J)$ indices (Begon et al., 1996) were calculated for each treatment plot using the proportion of soil cover of each species in relation to total plant cover and e-base logarithms. The oven-dry biomass of understory vegetation was organised in a similar way, integrated for each treatment plot and expressed in an area basis. Stem volume of stand was calculated by the sum of estimated stem tree volumes and expressing the result by surface area.

The number of species, proportion of plant cover, diversity and equitability indices, understory biomass and stem volume were statistically compared between treatments using the SPSS Statistical Program for Windows, version 11.5 ( ${ }^{\circ}$ SPSS Inc.). The normality of data distribution was confirmed by Kolmogorov-Smirnov test and the homogeneity of variance tested using the Levene test. Data that did not fit homogeneity of variance were $\log (x+1)$ transformed. Where homogeneity of variance was confirmed, comparisons were made using OneWay ANOVA and multiple comparison Tukey test, considering treatments as independent variable and the estimated parameters as dependent variables. When variance was not equal, even following data transformation, the averages were compared using Dunnett's T3 test. The significance level of 0.05 was used in all statistical analyses.

Whenever temporal trends were apparent, linear regression analysis was used to determine statistical significance and data fitness of such tendencies.

\section{Results and discussion}

\subsection{Number of species}

During the experimental period the mean total number of species per treatment plot was greatest in $\mathrm{C}$ and least in treatment HF (Table 1). However, statistically significant differences between treatments occurred only 1 and 8 years after treatment application. At the end of rotation, in the 8th year, both $\mathrm{H}$ and $\mathrm{HF}$ treatments had significantly less species than $\mathrm{C}$, suggesting a negative long-term effect of harrowing on species richness. The average number of species only exceptionally reached 10 per $250 \mathrm{~m}^{2}$ plot in treatment $\mathrm{H}$ in the 2 nd year. It was always higher than 12 in treatments $\mathrm{C}$ and $\mathrm{F}$ in the first 3 years, decreasing in the 7th and 8th years on the $\mathrm{C}$ and F plots. Fabião et al. (2002) also reported greater species richness in understory vegetation of eucalyptus plantations with less disturbance at the time of planting than in those with greater disturbance. Neary et al. (2001) states a common assumption that species richness is negatively affected in forest plantations following major disturbances.

A general decrease of species richness over time was observed in all treatments and may be related to competition for light, water, and nutrients with the eucalyptus trees. However, such a trend was not statistically significant when analysed by linear regression. Variation in the number of species over time in previous studies performed in eucalyptus plantations in Central Portugal has been partially explained by the scarcity or abundance of winter and spring rainfall (Fabião et al., 2002; Carneiro et al., 2007).

Table 1

Average number of understory species in treatment plots

\begin{tabular}{|c|c|c|c|c|}
\hline \multirow[t]{2}{*}{ Years } & \multicolumn{4}{|c|}{ Treatments } \\
\hline & C & $\mathrm{F}$ & $\mathrm{H}$ & $\mathrm{HF}$ \\
\hline 1997 & $13.3 \mathrm{a}$ & $12.5 \mathrm{ab}$ & $7.3 \mathrm{ab}$ & $5.8 \mathrm{~b}$ \\
\hline 1998 & 16.8 & 15.5 & 10.5 & 9.5 \\
\hline 1999 & 13.8 & 12.8 & 8.3 & 6.5 \\
\hline 2003 & 9.5 & 8.3 & 7.0 & 6.3 \\
\hline 2004 & $11.5 \mathrm{a}$ & $9.5 \mathrm{ab}$ & $7.0 \mathrm{~b}$ & $6.5 \mathrm{~b}$ \\
\hline
\end{tabular}

The values followed by different letters in the same line were statistically different $(p<0.05$, ANOVA procedure and Tukey test). Treatments are: $\mathrm{C}$, control; F, fertilisation; $\mathrm{H}$, harrowing; $\mathrm{HF}$, harrowing and fertilisation together in the same plots. 
Table 2

Average proportion (\% of total area, including uncovered soil) of understory plant cover in treatment plots

\begin{tabular}{|c|c|c|c|c|}
\hline \multirow[t]{2}{*}{ Years } & \multicolumn{4}{|c|}{ Treatments } \\
\hline & $\mathrm{C}$ & $\mathrm{F}$ & $\mathrm{H}$ & $\mathrm{HF}$ \\
\hline 1997 & $41.2 \mathrm{a}$ & $48.3 \mathrm{a}$ & $11.5 \mathrm{~b}$ & $3.9 \mathrm{~b}$ \\
\hline 1998 & $41.5 \mathrm{a}$ & $38.2 \mathrm{ab}$ & $10.3 \mathrm{bc}$ & $5.7 \mathrm{c}$ \\
\hline 1999 & $58.5 \mathrm{a}$ & $61.6 \mathrm{a}$ & $12.0 \mathrm{~b}$ & $5.4 \mathrm{~b}$ \\
\hline 2003 & 27.7 & 32.5 & 23.9 & 8.9 \\
\hline 2004 & $48.2 \mathrm{a}$ & $36.4 \mathrm{ab}$ & $30.3 \mathrm{ab}$ & $11.5 \mathrm{~b}$ \\
\hline
\end{tabular}

The values followed by different letters in the same line were statistically different ( $p<0.05$, ANOVA procedure and Tukey test). Treatments are given in Table 1 .

\subsection{Proportion of soil cover}

The HF plots consistently had the smallest proportion of soil cover by understory vegetation, with statistically significant differences between treatments in most years, except the 7 th year (Table 2). Treatments $\mathrm{C}$ and $\mathrm{F}$ had the largest proportion of soil cover, with the maximum values 3 years after treatment application (59\% and 62\%, respectively). However, in the 7 th and 8th years following treatments, plant cover decreased (to $48 \%$ and $36 \%$, respectively), whereas a significant increase was observed in treatments with harrowing, reaching $30 \%$ in $\mathrm{H}$ and $12 \%$ in $\mathrm{HF}$ at the end of the rotation. As a result, these treatments significantly increased their proportion of soil cover over time $\left(R^{2}=0.93, p<0.007\right.$ in treatment $\mathrm{H} ; R^{2}=0.94$, $p<0.006$ in $\mathrm{HF})$.

During the experiment, three plant families dominated the proportion of understory soil cover in all treatments (Fig. 1). Gramineae was the dominant family in treatment $\mathrm{H}$ throughout the study period, a finding similar to other authors (Locasio et al., 1990; Peltzer et al., 2000; Zobrist et al., 2005), who found that increasing mechanical disturbances in forest stands tended to favour grasses. An unexpected result was the greater proportion of soil cover by Funariaceae in F and HF plots, because declines in moss cover after nutrient addition have been reported in fertilisation studies performed in Boreal forest (Kellner, 1993), Hawaiian montane forests (Ostertag and Verville, 2002) and north temperate Douglas fir plantations (Thomas et al., 1999). However, the climatic conditions of these studies clearly differ from those of this experiment. This suggests that fertiliser application together with year-round, high early morning atmosphere humidity may have enhanced conditions favourable to moss growth in these low nutrient status soils.

Our results also show that the presence of Ericaceae during the first 3 years in treatments $\mathrm{C}$ and $\mathrm{F}$ may be related to the absence of mechanical disturbance through harrowing. In the 7th and 8th years after treatment application, the importance of Ericaceae decreased with Gramineae occupying the highest proportion of soil cover in the $\mathrm{C}, \mathrm{F}$, and $\mathrm{H}$ treatments after 8 years. Only in the HF treatment plots grasses were not the most significant family of understory plants. Although other studies also report that understory floristic composition does change over time (e.g. Loumeto and Huttel, 1997) their results contrast with those observed in the present study (i.e. short grasses in young stands, and shrubs and small trees in older stands).

\subsection{Shannon-Wiener diversity and equitability indexes}

In the $\mathrm{H}$ and $\mathrm{HF}$ plots, understory vegetation had consistently lower Shannon-Wiener diversity index values (Table 3). However, significant differences between treatments only occurred in the 1 st and 3rd years between treatment $\mathrm{C}$ and $\mathrm{HF}$. Treatment $\mathrm{C}$ ranked the greatest diversity index during the experimental period.
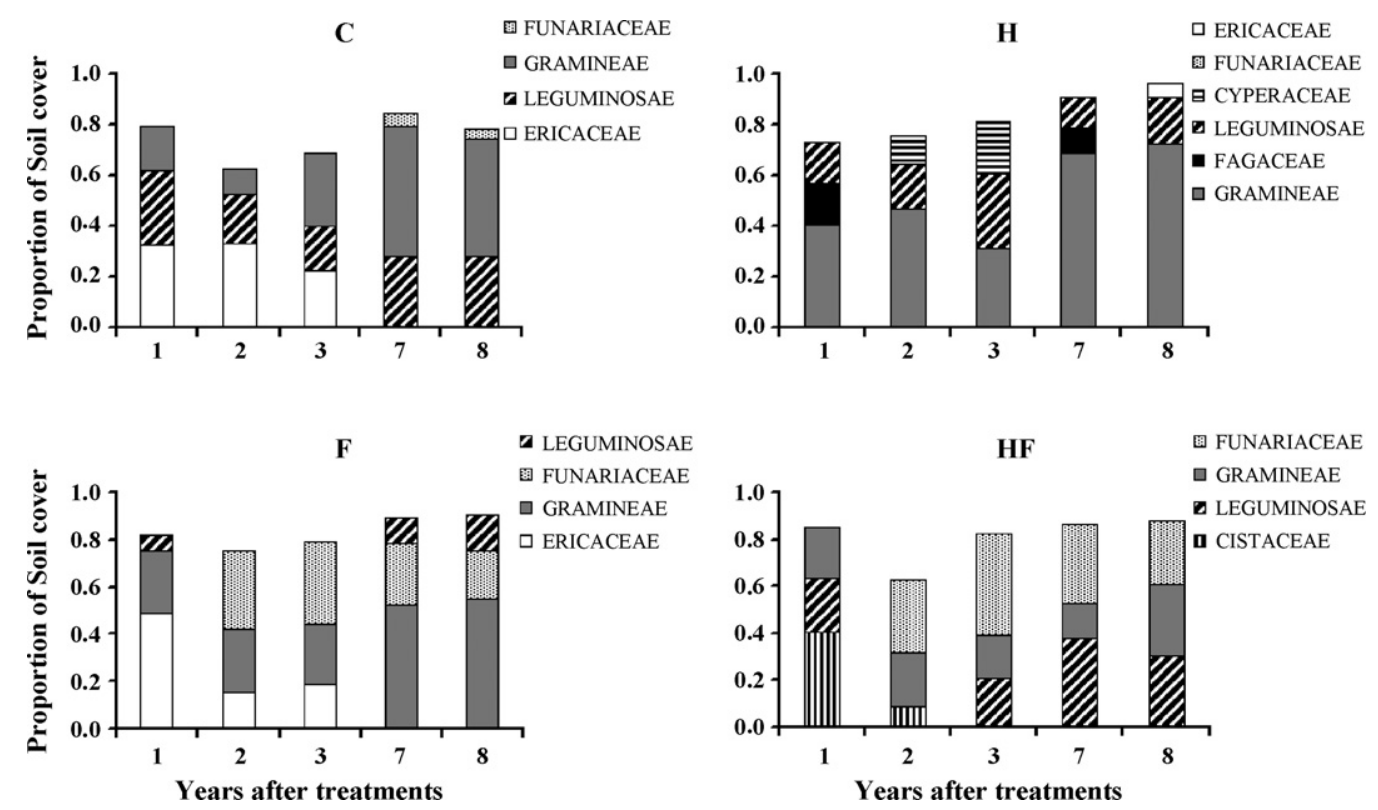

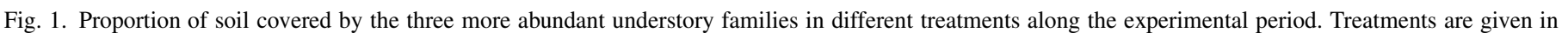
Table 1. 
Table 3

Shannon-Wiener diversity index in treatment plots

\begin{tabular}{|c|c|c|c|c|}
\hline \multirow[t]{2}{*}{ Years } & \multicolumn{4}{|c|}{ Treatments } \\
\hline & $\mathrm{C}$ & $\mathrm{F}$ & $\mathrm{H}$ & $\mathrm{HF}$ \\
\hline 1997 & $2.042 \mathrm{a}$ & $1.961 \mathrm{ab}$ & $0.970 \mathrm{ab}$ & $1.206 \mathrm{~b}$ \\
\hline 1998 & 2.100 & 1.966 & 1.422 & 1.719 \\
\hline 1999 & $2.187 \mathrm{a}$ & $1.843 \mathrm{ab}$ & $1.531 \mathrm{ab}$ & $1.186 \mathrm{~b}$ \\
\hline 2003 & 1.637 & 1.498 & 1.335 & 1.325 \\
\hline 2004 & 1.757 & 1.619 & 1.302 & 1.509 \\
\hline
\end{tabular}

The values followed by different letters in the same line were statistically different $(p<0.05$, ANOVA procedure and Dunnett's T3 and Tukey test). Treatments are given in Table 1.

The apparent divergence in the diversity index between treatments is related to differences in the average number of species in each treatment and year, confirmed by the absence of significant differences in the equitability index between treatments (Table 4). The highest equitability index values were observed in treatments $\mathrm{C}$ (1st- and 3rd-year) and HF (2nd, 7th- and 8th-year), whereas treatment $\mathrm{H}$ ranked the minimum value with an exception 3 years after treatment (treatment $F$ ).

It has been reported that nutrient additions may have either positive or negative effects on forest understory diversity (Thomas et al., 1999; Zobrist et al., 2005). In this experiment, the absence of a significant change in diversity index following fertilisation alone, suggests that understory vegetation was not affected by nutrient availability. As treatment HF had consistently lower diversity indices than $\mathrm{F}$ and treatment $\mathrm{H}$ lower than $\mathrm{C}$, it appears that harrowing was the main factor limiting short-term diversity of understory vegetation. Nevertheless, treatment $\mathrm{F}$ diversity significantly decreased over time $\left(R^{2}=0.89 ; p<0.017\right)$.

A review by Neary et al. (2001) documented that for most studies that have closely examined the effects of mechanical site preparation practices on plant diversity, the type of disturbance had no effect or increased plant diversity. In this experiment, harrowing strongly reduced short-term understory species richness, both alone and together with fertilisation, but at the end of rotation (8 years later) differences between treatments were not statistically significant. Although treatments were applied in a 5-year-old plantation, the result suggests that at the end of the rotation the effect of harrowing in understory diversity was negligible. This statement should be clarified by further

Table 4

Shannon-Wiener equitability index in treatment plots

\begin{tabular}{lllll}
\hline Years & \multicolumn{2}{l}{ Treatments } & & \\
\cline { 2 - 5 } & C & F & H & HF \\
\hline 1997 & 0.794 & 0.786 & 0.549 & 0.706 \\
1998 & 0.751 & 0.722 & 0.621 & 0.802 \\
1999 & 0.838 & 0.736 & 0.757 & 0.818 \\
2003 & 0.732 & 0.717 & 0.686 & 0.745 \\
2004 & 0.722 & 0.718 & 0.684 & 0.821 \\
\hline
\end{tabular}

The differences between treatments were not statistically significant $(p>0.05$, ANOVA procedure). Treatments are given in Table 1.

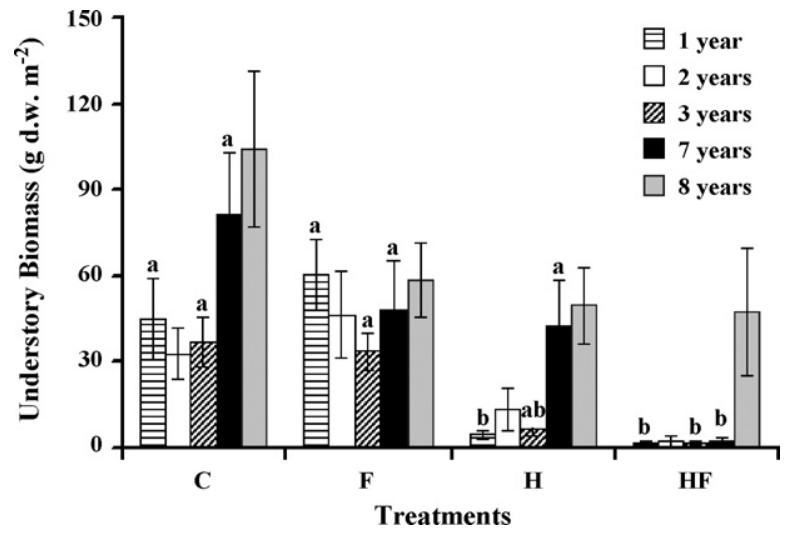

Fig. 2. Variation of the understory biomass according to years after treatment. The vertical bars represent \pm 1 S.E. Vertical bars with different characters were statistically different ( $p<0.05$, ANOVA procedure and Tukey test). Treatments are given in Table 1.

research given the paucity of research on the effect of silvicultural practices carried out in the middle of rotation.

\subsection{Biomass}

Biomass of understory vegetation was consistently lower in treatment $\mathrm{HF}$ during the period, with differences between treatments statistically significant in the $1 \mathrm{st}, 3 \mathrm{rd}$ and 7 th year after treatments (Fig. 2). In the first 3 experimental years, the understory biomass, averaging $30-60 \mathrm{~g} \mathrm{~m}^{-2}$ in $\mathrm{F}$ and $\mathrm{C}$, never exceeded $13.4 \mathrm{~g} \mathrm{~m}^{-2}$ (treatment $\mathrm{H}$ in the 2nd year) in treatments with harrowing, showing a good relationship with the proportion of soil cover by understory vegetation $(4-12 \%$ in $\mathrm{H}$ and $\mathrm{HF}$, and $38-62 \%$ in $\mathrm{F}$ and $\mathrm{C}$ ). In the 7th and 8th years after treatments, differences in the understory biomass were less pronounced, but $\mathrm{C}$ plots consistently had the greatest value, reaching the maximum 8 years after treatments $\left(104 \mathrm{~g} \mathrm{~m}^{-2}\right)$. The general increase in biomass over 8-year period was possibly related to the increasing importance of some woody species such as Pterospartum tridentatum and Cistus inflatus, especially on the HF plots.

Fertiliser application had a positive effect on understory biomass in treatment $\mathrm{F}\left(61 \mathrm{~g} \mathrm{~m}^{-2}\right)$ in the 1st year following the application. Nevertheless, biomass values in fertilised plots were never significantly different from $\mathrm{C}$ treatment. At the end of the experimental period, treatment $\mathrm{F}$ was the only one that did not show an increase in biomass compared to the 1st year, whereas $\mathrm{C}$ and $\mathrm{H}$ significantly increased their understory biomass over time $\left(R^{2}=0.87, p<0.021\right.$ in $\mathrm{C} ; R^{2}=0.94$, $p<0.006$ in $\mathrm{H}$ ). Several authors reported that fertiliser application can benefit wildlife by increasing understory vegetation growth (Hunter, 1990; Zobrist et al., 2005). Our study showed that fertilisation has no significant effect on available resources for wildlife, whereas harrowing may reduce those resources in the short term.

As reported in previous experiments in E. globulus plantations (Fabião et al., 2002; Carneiro et al., 2007), the major contribution of Funariaceae to the proportion of 
understory plant cover in the $3 \mathrm{rd}$ and 7 th years in treatment $\mathrm{HF}$ (cf. Fig. 1) did not correspond to a parallel increase in biomass, due to the small stature of the mosses. However, in the 8th year an increase in understory biomass in that treatment may be related to a parallel increase in the importance of some woody species, such as $P$. tridentatum and $C$. inflatus. This apparently was the main reason for the lack of statistically significant differences between treatment HF and the others, still observed in the previous year. Therefore, biomass values measured after 13 years of stand development suggest that harrowing eucalyptus plantations in the middle of rotation negatively affected the development of understory vegetation. However, statistically significant differences were only observed at the beginning of the study period becoming much smaller and not significant at the end of the rotation.

\subsection{Stem volume}

No significant difference was found in stand stem volume at the end of the experiment, although the final values clearly ranked $\mathrm{H} \quad\left(265 \mathrm{~m}^{3} \mathrm{ha}^{-1}\right)>\mathrm{F} \quad\left(229 \mathrm{~m}^{3} \mathrm{ha}^{-1}\right)>\mathrm{C}$ $\left(219 \mathrm{~m}^{3} \mathrm{ha}^{-1}\right)>\mathrm{HF}\left(217 \mathrm{~m}^{3} \mathrm{ha}^{-1}\right)$. This ranking was apparently related to differences in both average dbh and tree height, which were significantly smaller in treatment HF $(14 \mathrm{~cm} \mathrm{dbh}$, $20 \mathrm{~m}$ height) than in $\mathrm{F}$ and $\mathrm{H}(16 \mathrm{~cm}, 22 \mathrm{~m})$, whereas $\mathrm{C}$ had intermediate $\mathrm{dbh}$ value $(15 \mathrm{~cm}, 22 \mathrm{~m})$.

The increase in stem volume promoted by harrowing, although not statistically significant, may be interesting from a timber production perspective. This effect seems to be high enough to be distinct from that resulting from fertilisation, alone or with harrowing, and may be of economic interest for the timber production and trade sectors. However, the costs of harrowing may make the practice economically unviable at these modest gains in growth. Nevertheless, the results obtained in this study indicate that this silvicultural practice carried out in the middle of rotation has a short-term negative effect on species richness and abundance of understory vegetation. In short rotation systems, such as eucalyptus plantations, repeated disturbance of the vegetation after harvesting will result in a cyclic return to early succession phases of that vegetation.

\section{Conclusions}

Harrowing applied at middle rotation decreased understory species richness, proportion of soil cover, species diversity and biomass. The decrease of understory vegetation biomass may also diminish fuel load and fire risk. Nevertheless, in spite of the decrease of understory vegetation cover and biomass, timber production was not significantly affected by harrowing, with or without fertilisation. At the end of the experiment, fertiliser application also had negligible effects on understory vegetation and tree growth. As these practices did not promote significant tree growth and had some negative effects in understory vegetation, they are questionable from the economic and environmental point of view. Because very few studies have examined the effects of silvicultural practices in the middle of rotation (e.g. harrowing and fertilisation) on understory vegetation, further research is needed for a better understanding of both their short- and long-term effects.

\section{Acknowledgements}

Funding for this study was provided by JNICT/FCT, Portugal (Project PRAXIS XXI 3/3.2/FLOR/2123/95 and M. Carneiro's PhD grant SFRH/BD/14366/2003) and PAMAF and AGRO Programs (Ministry of Agriculture), Portugal (Projects PAMAF4110.4029.0350/95 and AGRO 19). The Störa Enso (CELBI) Pulp Company is gratefully acknowledged for allowing the use of one of its eucalyptus plantations and for helpful assistance in field work. The authors also thank Samantha Jane Hughes for English revision of the text and two anonymous referees for helpful suggestions that contributed to text clarity.

\section{References}

Alves, A.A.M., 1994. Um quadro para o debate da problemática do eucalipto. In: Eucalipto Economia e Território, Cosmos/S.P.E.R., Lisboa.

Alves, A.A.M., Pereira, J.M.S., Borges, J.G.C., Borges, G.C., Carvalho, P.O., David, J.S., Gonçalves, J.H.C., Madeira, M., Onofre, N., Valente, F., 1990. Impactes Ambientais e Sócio-Económicos do Eucaliptal em Portugal. Departamento de Engenharia Florestal, Universidade Técnica de LisboaInstituto Superior de Agronomia, Lisboa.

Aubert, M., Alard, D., Bureau, F., 2003. Diversity of plant assemblages in managed temperate forests: a case study in Normandy (France). Forest Ecol. Manage. 175, 321-337.

Bauhus, J., Aubin, I., Messier, C., Connell, M., 2001. Composition, structure, light attenuation and nutrient content of understory vegetation in a Eucalyptus sieberi regrowth stand 6 years after thinning and fertilisation. Forest Ecol. Manage. 144, 275-286.

Begon, M., Harper, J.L., Townsend, C.R., 1996. Ecology. Individuals, Populations and Communities, 3rd ed. Blackwell Science, Oxford.

Bengtsson, J., Nilsson, S.G., Franc, A., Menozzi, P., 2000. Biodiversity, disturbances, ecosystem functions and management of European forests. Forest Ecol. Manage. 132, 39-50.

Bernaldez, F.G., Perez, R.P., Levassor, C., 1989. Effets des Plantations d'Eucalyptus dans le Nord d'Espagne. Commission des Communautés Européennes, Brussels.

Brosofske, K.D., Chen, J., Crow, T.R., 2001. Understory vegetation and site factors: implications for a managed Wisconsin landscape. Forest Ecol. Manage. 146, 75-87.

Carneiro, M., Fabião, A., Martins, M.C., Cerveira, C., Santos, C., Nogueira, C., Lousã, M., Hilário, L., Fabião, André, Abrantes, M., Madeira, M., 2007. Species richness and biomass of understory vegetation in a Eucalyptus globulus Labill. coppice as affected by slash management. Eur. J. Forest Res. 126, 475-480.

Carnus, J.M., Parrotta, J., Brockerhoff, E.G., Arbez, M., Jactel, H., Kremer, A., Lamb, D., O'Hara, K., Walters, B., 2003. Planted Forests and Biodiversity. UNFF Intersessional Experts Meeting on the Role of Planted Forests in Sustainable Forest Management, New Zealand.

Costa, J.C., Capelo, J., Lousã, M., Espírito-Santo, M.D., 2002. Os sobreirais do Divisório Português: Asparago aphylli-Quercetum suberis. Quercetea 3,8198.

Cutini, A., Matteucci, G., Mugnozza, G.S., 1998. Estimation of leaf area index with the Li-Cor LAI 2000 in deciduous forests. Forest Ecol. Manage. 105, 55-65.

Driessen, P., Deckers, J., Spaargaren, O., Nachtergaele, F., 2001. Lecture notes on the major soils of the world. World Soil Resources Reports 94. FAO, Rome.

Fabião, A., Martins, M.C., Cerveira, C., Santos, C., Lousã, M., Madeira, M., Correia, A., 2002. Influence of soil and organic residue management on biomass and biodiversity of understory vegetation in a Eucalyptus globulus Labill. plantation. Forest Ecol. Manage. 171, 87-100. 
Hartley, M.J., 2002. Rationale and methods for conserving biodiversity in plantation forests. Forest Ecol. Manage. 155, 81-95.

Hunter, M.L., 1990. Wildlife, Forests, and Forestry: Principles of Managing Forests for Biological Diversity. Prentice-Hall, Englewood Cliffs, New Jersey.

Kellner, O., 1993. Effects on associated flora of sylvicultural nitrogen fertilization repeated at long intervals. J. Appl. Ecol. 30, 563-574.

Kent, M., Coker, P., 1992. Vegetation Description and Analysis. A Practical Approach. Belhaven Press, London.

Locasio, C.G., Lockaby, B.G., Caulfield, J.P., Edwards, M.B., Causey, M.K., 1990. Mechanical site preparation effects on understory plant diversity in the Piedmont of the southern USA. New Forests 4, 261-269.

Loumeto, J.J., Huttel, C., 1997. Understory vegetation in fast-growing tree plantations on savanna soils in Congo. Forest Ecol. Manage. 99, 65-81.

Marques, P.M.P., 1997. Gradagem e Fertilização num Povoamento de Eucalyptus globulus Labill. Efeitos a Curto Prazo. Relatório do Trabalho de Fim de Curso de Engenharia Florestal. Instituto Superior de Agronomia, Lisboa.

Moore, S.E., Allen, H.L., 1999. Plantation forestry. In: Hunter, Jr., M.L. (Ed.), Maintaining Biodiversity in Forest Ecosystems. Cambridge University Press, Cambridge, pp. 400-433.

Neary, D.G., Moir, W.H., Phillips, B.G., 2001. Harvesting-related soil disturbance: implications for plant biodiversity and invasive weeds. In: Richardson, J., Bjorheden, R., Hakkila, P., Lowe, A.T., Smith, C.T. (Comp.), Bioenergy From Sustainable Forestry: Principles and Practice. Proceedings of IEA Bioenergy Task 18 Workshop, Coffs Harbour, New South Wales, Australia, October 16-20, 2000, New Zealand Forest Research Institute, Forest Research Bulletin No. 223, pp. 17-32.

Neary, D.G., Moir, W.H., Overby, S.T., 2002. Role of soil disturbances in determining post-harvest plant biodiversity and invasive weed distributions. In Frochot, H., Collet, C., Balandier, P. (Compilers), Popular Summaries from the 4th International Conference on Forest Vegetation Management. Institut National de la Recherche Agronomique, Nancy, France, pp. 52-54.

Ostertag, R., Verville, J.H., 2002. Fertilization with nitrogen and phosphorus increases abundance of non-native species in Hawaiian montane forests. Plant Ecol. 162, 77-90

Patel-Weynand, T., 2002. Biodiversity and sustainable forestry: state of the science review. Report for the National Commission on Science for Sustainable Forestry, Washington, DC, 54 pp.
Peltzer, D.A., Bast, M.L., Wilson, S.D., Gerry, A.K., 2000. Plant diversity and tree responses following contrasting disturbances in boreal forest. Forest Ecol. Manage. 127, 191-203.

Ramovs, B.V., Roberts, M.R., 2003. Understory vegetation and environment responses to tillage, forest harvesting, and conifer plantation development. Ecol. Appl. 13 (6), 1682-1700.

Reis, R.M., Gonçalves, M.Z., 1981. Caracterização Climática da Região Agrícola do Ribatejo e Oeste. O Clima de Portugal. Fascículo XXXII. Instituto Nacional de Meteorologia e Geofísica, Lisboa.

Roberts, M.R., 2004. Response of the herbaceous layer to natural disturbance in North American forests. Can. J. Botany 82, 1273-1283.

Roberts, M.R., Gilliam, F.S., 1995. Patterns and mechanisms of plant diversity in forested ecosystems: implications for forest management. Ecol. Appl. 5 (4), 969-977.

Roberts, M.R., Zhu, L., 2002. Early response of the herbaceous layer to harvesting in mixed coniferous-deciduous forest in New Brunswick, Canada. Forest Ecol. Manage. 155, 17-31.

Rosa, M.L., Gomes, M.F., Espírito-Santo, M.D., 1986. Influência de factores ecológicos e fitotécnicos na Flora espontânea de sistemas florestais da região de Castelo Branco. In: $1^{\circ}$ Congresso Florestal Nacional. Fundação Calouste Gulbenkian, Lisboa, pp. 255-260.

Thomas, S.C., Halpern, C.B., Falk, D.A., Liguori, D.A., Austin, K.A., 1999. Plant diversity in managed forests: understory responses to thinning and fertilization. Ecol. Appl. 9 (3), 864-879.

Tisdall, J.M., Oades, J.M., 1982. Organic matter and water stable aggregates in soils. J. Soil Sci. 33, 141-163.

Tomé, J., 1990. Estimação do volume total, de volumes mercantis e modelação do perfil do tronco em Eucalyptus globulus Labill. Dissertação apresentada para obtenção do grau de Mestre em Produção. Vegetal. Instituto Superior de Agronomia, Lisboa.

Zbyzewski, G., Medeiros, A.C., Ferreira, O.V., 1966. Notícia Explicativa da Folha 30B, Bombarral. Serviços Geológicos de Portugal, Lisboa.

Zobrist, K.W., Hinckley, T.M., Andreu, M.G., 2005. A literature review of management practices to support increased biodiversity in intensively managed loblolly pine plantations. Final Technical Report to the National Commission on Science for Sustainable Forestry (NCSSF). In http:// www.ruraltech.org (Consulted in August 2006). 